Çukurova Üniversitesi Mühendislik Fakültesi Dergisi, 36(2), ss. 401-407, Haziran 2021

Cukurova University Journal of the Faculty of Engineering, 36(2), pp. 401-407, June 2021

\title{
Production of Biodiesel from in Vitro Grown Jojoba Calli Oil and a Comparison with Jojoba Biodiesel
}

\author{
Zeynep ERGÜN*1，Hasan SERINN²，Kadir AYDIN ${ }^{3}$, Saadet BÜYÜKALACA ${ }^{4}$ \\ ${ }^{1}$ Adana Alparslan Türkes Science and Technology University, Department of Bioengineering, \\ Adana \\ ${ }^{2}$ Cukurova University, Faculty of Engineering, Department of Automotive Engineering, Adana \\ ${ }^{3}$ Cukurova University, Faculty of Engineering, Department of Mechanical Engineering, Adana \\ ${ }^{4}$ Cukurova University, Faculty of Agriculture, Department of Horticulture, Adana (Deceased)
}

Geliş tarihi: 12.04.2021 Kabul tarihi: 30.06.2021

\begin{abstract}
In this study, the fuel characteristics of biodiesel produced from jojoba [Simmondsia chinensis (Link) Schneider] oil and biodiesel obtained from the jojoba oil procured under laboratory conditions were compared. For this purpose, jojoba seed endosperm and oil, which was attained from the jojoba endosperm calli via soxhlet extraction, was obtained. Biodiesel was produced from this oil via the transesterification method. It was determined that the fuel characteristics of the biodiesels produced from the oil procured under the laboratory conditions and the oil attained from the seeds were close to each other, and it was observed that the other features were in parallel with the standards, except for the viscosity and freeze point. This research study offers a solution for the raw material problem, which is one of the most important obstacles against the widespread use of biodiesel, in terms of environmental and economic aspects.
\end{abstract}

Keywords: Plant tissue culture, Callus, Biodiesel, Transesterification, Jojoba

\section{In Vitro Koşullarda Geliştirilen Jojoba Kallus Yağından Biyodizel Üretimi ve Jojoba Biyodizeli ile Karşılaştırılması}

$\ddot{\mathbf{O} z}$

$\mathrm{Bu}$ çalışmada doğrudan jojoba [Simmondsia chinensis (Link) Schneider] yağından ve laboratuvar koşullarında elde edilen jojoba yağından üretilmiş olan biyodizellerin karakteristikleri karşılaştırılmıştır. $\mathrm{Bu}$ amaçla sokslet yöntemi ile jojoba endosperm yağı ve jojoba endospermi kalluslarından üretilmiş yağ ekstrakte edilmiştir. Biyodizel üretimi için transesterifikasyon yönteminden faydalanılmıştır. Doğrudan jojoba endosperminden üretilen ve laboratuvar koşullarında geliştirilen jojoba endosperm kalluslarından üretilen yağlardan elde edilen biyodizel örneklerinin yakıt karakteristiklerinin birbirine çok yakın olduğu, vizkosite ve donma noktası dışında standartlara uygun olduğu görülmüştür. Bu çalışma biyodizelin geniş kullanım alanı elde etmesindeki en önemli sorun olan ham madde sorununa, çevresel ve ekonomik açılardan bir çözüm önerisi niteliğindedir.

Anahtar Kelimeler: Bitki doku kültürü, Kallus, Biyodizel, Transesterifikasyon, Jojoba

*Sorumlu yazar (Corresponding author): Zeynep ERGÜN, zergun@atu.edu.tr 


\section{INTRODUCTION}

With a high raw material cost, biodiesel, which is produced from herbal, animal, and waste oil, is an alternative fuel for diesel [1-3].

The major plants used as raw material for biodiesel studies are jojoba, soybean, canola, castor oil, tea seed, terebinth, sesame, bay, sunflower, safflower, corn, loquat, poppy, walnut, hazelnut, almond, olive, kaju, pistachio, pine nuts, peanuts, date, garnet, black seed, nettle seed, mustard, turmeric, cedar tree, ginger, avocado, menthol, henna, cumin, green tea, hemp, pepper, rosemary, cotton, coffee, peppermint, orange peel, kiwi, linen, coconut, jathropha, soapberry, and the seeds of various vegetables and fruits [4-11].

The seeds of jojoba plant (Simmondsia chinensis Link), which is a member of Simmondsiaceae family known for their precious oily seeds, contain oil ranging from $45 \%$ to $60 \%$. With its liquid wax structure, which is called wax, the oil produced from the seeds of jojoba is chemically different from other herbal oils. Although the oils produced from the herbal seeds are triglyceride, waxy oils such as jojoba oil and whale oil are wax esters. The composition of the oil changes during the maturation of the seeds and storage. Moreover, the oil-ester compositions of the seeds can preserve their characteristics even after 25 years from the harvest. Mainly used in lubrication, leather production, cosmetics, and the drug industry, jojoba oil is used in the production of hard white wax, which is used in lubricants, desiccants, emulsifiers, resins, protective coaters, disinfectants, detergents, slip-coaters, tanning creams, polishes for floors, shoes, and cars, as well as in the preparation of numerous different substances [12-14].

Since it is a sustainable and renewable energy source, biodiesel has an important place among various energy sources. However, due to raw material insufficiency, it could not excel petrodiesel concerning the price; therefore, it is not produced and consumed at desired levels. Raw material cost forms a major part of the biodiesel production costs. Moreover, a remarkable part of the raw materials used in biodiesel production is also strategic foodstuff, which adds another dimension to the issue. Considering that nutrition problems come to the fore with today's rapid population growth, it would be wise to mention that the priority in oil consumption should be given to the food sector.

If the desired situation is the use of biodiesel instead of petro-diesel or a mixture of both, it is a non-negligible fact that the raw material costs of biodiesel should be decreased.

Within the context of this study, previous studies were examined, which asserted that the oil proportion increased via tissue culture under laboratory conditions [15], and the callus culture method was used to increase the oil proportion of the jojoba seeds. Thus, it was aimed to obtain oil under laboratory conditions. It was aimed to produce biodiesel from these calli under laboratory conditions, and to examine the fuel features of biomass-based biodiesel.

\section{MATERIAL AND METHODS}

In this study, jojoba [Simmondsia chinensis (Link) Schneider] seeds were used. Methyl-alcohol [1618] was used as the alcohol and sodium hydrochloride $(\mathrm{NaOH})$ [17,18] (Marchetti et al. 2007; Shah et al. 2014) as the catalyst. MS [19] was used as the essential nutrition habitat, and 2,4 D, BAP, 2 Ip and NAA were used as the growth improver. Sucrose was used to meet the energy need, and agar was used for comparing the nutrition habitats.

\subsection{Obtaining Callus from Jojoba Endosperm}

Jojoba seeds were sterilized for 20 minutes under laboratory conditions within $20 \%$ sodium hypochlorite solution. After being washed four times under sterile purified water, they were kept in sterile purified water for one day, thereafter their endosperms were taken. The endosperms were placed in a nutrition habitat involving $\mathrm{MS}+1$ mg/l 2 İp+1 mg/l NAA+30 g/l sucrose+8 g/l agar. 
To provide cellular multiplication, these materials were transferred to a conditioning chamber (16 hours light, 8 hours darkness, and $26^{\circ} \mathrm{C}$ ). Calli were obtained from the endosperms placed in these nutrition habitats. Thus, cellular multiplication was provided.

\subsection{Obtaining Methyl Ester of Both Jojoba Endosperm and Jojoba Endosperm Callus Oil}

After the calli procured in the laboratory were grained, they were dehumidified by being kept in the stove for five hours at $105^{\circ} \mathrm{C}$.

Transesterification method, which is one of the biodiesel obtaining methods, was used in the study [20]. Transesterification reaction is cheaper, its reaction time is shorter and it has a better production capacity. Since they take place under lower temperatures and in a shorter time, they are commercially the most preferred alkali $(\mathrm{NaOH}$, $\mathrm{KOH}$ ) catalyst reactions [21,22]. To obtain methyl ester from raw jojoba endosperm callus and jojoba endosperm oil with the transesterification method, methanol [16-18] as much as $20 \%$ by volume of oil and $\mathrm{NaOH}[17,18]$ as much as $5 \%$ by weight of oil were mixed in a beaker. A magnetic stirrer was placed into the mixture, thus the $\mathrm{NaOH}$ was dissolved (methoxide formation) in the methanol. Alcohol catalyst mixture was put into the calandria and herbal oil, which was obtained using soxhlet extraction, was added on. To prevent alcohol evaporation, the system was completely closed to the atmosphere. After the saturated solution is provided, it was heated up to $60^{\circ} \mathrm{C}$ and the heated oils were mixed with sodium methoxide. This mixture was heated for 2 hours in a heating agitator. After the reaction was completed, for the phase separation of the two main products, glycerin and biodiesel, this mixture was taken from the heater, placed into a settling container, and kept there for 8 hours. The glycerin, which was cumulated in the lower phase, was removed from the setting. The alcohol, which was remained in glycerin and biodiesel, was removed from the setting as well. The catalyst and soap remnants within the biodiesel, from which glycerin was removed, were also removed.
Some characteristics of the extracted oils and biodiesels, which were produced from these oils, were measured such as intensity, cetane number, kinematic viscosity, fire point, free acid content, CFPP (Cold Filter Plugging Point), and lower heating value.

\section{RESULTS AND DISCUSSION}

In the context of this study, MS+1 mg/l $2 \dot{\mathrm{I} p}+1$ $\mathrm{mg} / \mathrm{l} \mathrm{NAA}+30 \mathrm{~g} / \mathrm{l}$ sakkaroz+8 $\mathrm{g} / \mathrm{l}$ agar setting was used for the jojoba endosperm explant. The oil ratio that was produced from the calli procured from this setting is given in Table 1.

Table 1. Oil percentages of the materials in the automatic soxhlet extractor

\begin{tabular}{|l|c|c|}
\hline \multirow{2}{*}{ Material } & $\begin{array}{c}\text { Oil rate } \\
\text { \% }\end{array}$ & $\begin{array}{c}\text { Average oil rate } \\
\text { \% }\end{array}$ \\
\hline \multirow{2}{*}{$\begin{array}{l}\text { Jojoba seed } \\
\text { endosperm }\end{array}$} & 44.87 & \multirow{2}{*}{44.36} \\
\cline { 2 - 2 } & 43.80 & \\
\cline { 2 - 2 } $\begin{array}{l}\text { Jojoba } \\
\text { endosperm } \\
\text { callus }\end{array}$ & 44.43 & \multirow{2}{*}{50.93} \\
\cline { 2 - 2 } & 50.27 & 51.26 \\
\hline
\end{tabular}

It was observed that the average of the oil content percentage of the jojoba seed endosperms was $44.36 \%$ in Table 1. As per the endosperm calli procured from jojoba endosperms, the average of the oil content percentages was determined as $50.93 \%$. In conclusion, the oil procured from the calli produced under laboratory conditions was $6.57 \%$ higher compared to the oil procured from the seed endosperms.

The biodiesel obtained from $275 \mathrm{ml}$ oil was 265 $\mathrm{ml}$, which was taken out of the oil procured from dry jojoba endosperm callus materials. $195 \mathrm{ml}$ of the oil, which was procured from dry jojoba endosperm callus materials, was used for biodiesel production, and $188 \mathrm{ml}$ biodiesel was obtained.

Within the scope of this research study, the fuel features of the jojoba endosperm oil, which was procured in the laboratory, and the oil, which was procured from seed endosperms, are given in Table 2. 
Table 2. Features of jojoba endosperm callus oil and jojoba endosperm oil

\begin{tabular}{|l|c|c|}
\hline Properties & Jojoba endosperm callus oil & Jojoba endosperm oil \\
\hline Density, $\mathrm{kg} / \mathrm{m}^{3}$ & 970 & 890 \\
\hline Cetane number & 57 & 53 \\
\hline Kinematic viscosity, $\mathrm{mm}^{2} / \mathrm{s}$ & 25.6 & 29 \\
\hline Flash point, ${ }^{\circ} \mathrm{C}$ & $>120$ & $>120$ \\
\hline Free fatty acid (FAA) & 2.9 & 1.4 \\
\hline
\end{tabular}

When Table 2 is examined, it is observed that the intensity of the callus oil is $80 \mathrm{~kg} / \mathrm{m}^{3}$ higher compared to endosperm oil. It is also seen that the cetane number of the jojoba callus oil is higher compared to the jojoba endosperm oil. It is conspicuous that the kinematic viscosity of jojoba callus oil is $3.4 \mathrm{~mm}^{2} / \mathrm{s}$ less compared to jojoba endosperm oil. The fire point was over $120^{\circ} \mathrm{C}$ for both. The free acid content of the jojoba callus oil was higher compared to the jojoba endosperm oil.
The features of the jojoba callus oil and the jojoba endosperm oil are in accord with each other except for the abovementioned differences.

In this research study, biodiesel was obtained from jojoba seed endosperm and jojoba endosperm calli, and the fuel features of the biodiesel were given in Table 3. The fuel features [23] are also given in the table as a benchmark.

Table 3. Fuel features of the biodiesel [23], which was obtained from jojoba endosperm calli and jojoba endosperm sample

\begin{tabular}{|l|c|c|c|c|c|c|}
\hline Properties & Diesel & EN590 & $\begin{array}{c}\text { Jojoba } \\
\text { endosperm callus } \\
\text { biodiesel }\end{array}$ & $\begin{array}{c}\text { Jojoba } \\
\text { endosperm } \\
\text { biodiesel }\end{array}$ & $\begin{array}{c}\text { ASTM D } \\
\text { 6751 }\end{array}$ & EN 14214 \\
\hline Density, $\mathrm{kg} / \mathrm{m}^{3}$ & 837 & $820-845$ & 863 & 865 & - & $860-900$ \\
\hline Cetane number & 59.47 & Min 51 & 68.5 & 63.2 & Min 47 & Min 51 \\
\hline $\begin{array}{l}\text { CFPP }(\text { Cold filter } \\
\text { plugging point), }{ }^{\circ} \mathrm{C}\end{array}$ & -12 & - & +12 & +13.7 & - & $\begin{array}{c}\text { Summer }<4.0 \\
\text { Winter }<-1.0\end{array}$ \\
\hline $\begin{array}{l}\text { Lower heating } \\
\text { value, } \mathrm{kJ} / \mathrm{kg}\end{array}$ & 45856 & - & 43102 & 43871 & - & - \\
\hline $\begin{array}{l}\text { Kinematic } \\
\text { viscosity, } \mathrm{mm}^{2} / \mathrm{s}\end{array}$ & 2.76 & $2.0-4.5$ & 19.2 & 21.3 & $1.9-6.0$ & $3.5-5.0$ \\
\hline Flash point, ${ }^{\circ} \mathrm{C}$ & 79.5 & Min 55 & $>120$ & $>120$ & Min 93 & Min 120 \\
\hline $\begin{array}{l}\text { Free fatty acids } \\
\text { (FAA) }\end{array}$ & - & - & 2.2 & 0.6 & - & - \\
\hline
\end{tabular}

Effecting fuel consumption and heat of combustion, the intensity of the biodiesel $\left(860-900 \mathrm{~kg} / \mathrm{m}^{3}, \quad 15^{\circ} \mathrm{C}, \quad \mathrm{EN} 1424\right)$ is higher compared to the fossil diesel fuel $\left(820-845 \mathrm{~kg} / \mathrm{m}^{3}\right.$, EN 590). The longer the hydrocarbon chain the less the intensity, the more increased the double bond the higher the intensity [24]. When the results are examined, it is observed that there is only a slight $\left(0.02 \mathrm{~kg} / \mathrm{m}^{3}\right)$ difference between jojoba endosperm callus biodiesel and jojoba endosperm biodiesel. Concerning the intensity, it was concluded that the biodiesel produced from oil, which was procured from callus, is suitable for the biodiesel sector. In previous studies, this value was reported as $0.866 \mathrm{~kg} / \mathrm{l}$ [25-28]. This result proves that our research study is convenient to the literature with regards to jojoba biodiesel intensity value.

If the number of cetane, which determines the ignition quality of the diesel fuels, is higher, it decreases the ignition lag. The cetane number of long straight-chain saturated hydrocarbons is higher. Cetane figure increases with longer 
hydrocarbons while decreasing with increased double bonds. Since it has a higher cetane number compared to classical diesel fuel, biodiesel has higher combustion efficiency [24]. There is a 5.3point difference between jojoba endosperm biodiesel and the jojoba oil biodiesel procured in the laboratory. In other words, concerning the cetane number, jojoba endosperm callus biodiesel has a better value compared to the jojoba endosperm biodiesel. When the previous research studies of the literature are compared, it is observed that the cetane figures are 63.5 [25-28] and 43.75 [29]. Considering that the castor oil biodiesel has a high cetane figure, which is 80 [30], it can be mentioned that the cetane number of the jojoba endosperm callus biodiesel (68.5) is in a significant level regarding biodiesel quality.

Liquidity of the fuel is critical in the fuel feeding system as the in-cylinder atomization of the fuel is critical in fire performance. High viscosity causes poor atomization of the fuel, bad fire, plugging in injections, and carbon cumulation in the piston rings. This situation decreases the spray of the injectors, necessitating high pumping pressure. The viscosity of the biodiesel is around $3.5-6 \mathrm{~mm}^{2} / \mathrm{sec}$, and it increases with longer hydrocarbon chains while decreasing with more double bonds. Impurity of the biodiesel and oxidation productions increases the viscosity [24]. In the study, the kinematic viscosity value was determined as $19.2 \mathrm{~mm}^{2} / \mathrm{s}$ for the jojoba endosperm callus biodiesel, while it was $21.3 \mathrm{~mm}^{2} / \mathrm{s}$ for jojoba endosperm biodiesel.

Öğuit and Oğuz [31] reported in their study that flashpoint was vital in risk classification of the fuels, that the flashpoint needed to be high for its transportation and storage. The flashpoint of the diesel fuel was $74^{\circ} \mathrm{C}$ while it was over $300^{\circ} \mathrm{C}$ for the herbal oil, and was $120-220^{\circ} \mathrm{C}$ for biodiesel. Evaluating the flashpoints in this study proved that the flashpoints of both the jojoba endosperm callus biodiesel and the jojoba endosperm biodiesel are over $120^{\circ} \mathrm{C}$ [32]. This proves that the flashpoint of the biodiesel produced from the oil under the laboratory conditions is available for transportation and storage.

\section{CONCLUSIONS}

In this study, which was conducted aiming to deliver a solution to the raw material problem and to present a different untried method to the science world, firstly, the oil was procured under the laboratory conditions, and second, biodiesel was obtained from this oil. The biodiesels, which were produced from the seed oil and under laboratory conditions, were compared. As the conclusion of the biodiesel analyses, it was observed that both of the diesels had similar features regarding fuel features. It was detected that all of the features are in accordance with the literature except for the viscosity and freeze point. It was determined that callus biodiesel procured under laboratory conditions can be used at a mixed proportion, even if not $100 \%$.

This study presents a solution suggestion for the raw material problem of biodiesel, which is emphasized to be more useful concerning environmental and economical aspects. With further development of the methods conducted, it seems possible to sufficiently amplify the herbal oils, which are among the raw materials of the biodiesel, with less material.

Production of biodiesel raw material under laboratory conditions will be useful for cheapening the raw material, for leading the oil production process in the desired quality, and for reducing the dependency on climate and terrain conditions in raw material provision.

\section{ACKNOWLEDGMENTS}

Data presented in the study were obtained from the Ph.D. thesis of Zeynep ERGÜN (corresponding author) entitled 'Obtaining Biodiesel from Cell Culture Of Some Oil Seed Plants' and this study was published as abstract at the $2^{\text {nd }}$ International Mediterranean Science and Engineering Congress (IMSEC 2017) proceeding book.

Funding: This work was supported by the Cukurova University, Scientific Research Projects 
Coordinating Office (project CU-BAP-FDK-20153072).

\section{REFERENCES}

1. Gerpen, J.V., 2005. Biodiesel Processing and Production. Fuel Processing Technology 86, 1097-1107.

2. Demirbaş, A., 2008. Biodiesel Production via Rapid Transesterification. Energy Sources, Part A: Recovery, Utilization and Environmental Effects, 30(19), 1830-1834.

3. Poddar, T., Jagannath, A., Almansoori, A., 2015. Biodiesel Production Using Reactive Distillation: A Comparative Simulation Study, Energy Procedia, 75, 17-22.

4. Chhetri, A.B., Tango, M.S., Budge, S.M., Watts, K.C., Islam, M.R., 2008. Non-Edible Plant Oils as New Sources for Biodiesel Production, International Journal of Molecular Sciences, 9(2),169-180.

5. Saydut, A., Duz, M.Z., Kaya, C., Kafadar, A.B., Hamamci, C., 2008. Transesterified Sesame (Sesamum indicum L.) Seed Oil as A Biodiesel Fuel, Bioresource Technology, 99(14), 6656-6660.

6. Basha, S.A., Gopal, K.R., Jebaraj, S., 2009. A Review on Biodiesel Production, Combustion, Emissions and Performance, Renewable and Sustainable Energy, 13, 1628-1634.

7. Özcanli, M., Serin, H., Aydin, K., Serin, S., 2011. Ricinus Communis (Castor Oil) Methyl Ester as a Natural Additive for Biodiesel Fuels, Energy Education Science and Technology Part A: Energy Science and Research, 27(2), 331-336.

8. Hoekman, S.K., Broch, A., Robbins, C., Ceniceros, E., Natarajan, M., 2012. Review of Biodiesel Composition, Properties, and Specifications, Renewable and Sustainable Energy Reviews, 16, 143-169.

9. Li-Bing, W., Hai-Yan, Y., Xiao-Hui, H., RuiYing, L., 2012. Influence of Fatty Acid Composition of Woody Biodiesel Plants on the Fuel Properties, Journal of Fuel Chemistry and Technology, 40(4), 397-404.

10. Talebian-Kiakalaieh, A., Amin, N.A.S., Mazaheri, H., 2013. A Review on Novel
Processes of Biodiesel Production from Waste Cooking Oil, Applied Energy, 104, 683-710.

11. Verma, P., Sharma, M.P., Dwivedi, G., 2016. Impact of Alcohol on Biodiesel Production and Properties, Renewable and Sustainable Energy Reviews, 56, 319-333.

12. Akdeşir, Ö., 2001. Antalya Koşullarında Tohumdan Yetiştirilen Jojoba (Simmondsia chinensis L.) Bitkilerinin Seleksiyonu ve Çoğaltılma Olanaklarının Saptanması Üzerine Araştırmalar, Akdeniz Üniversitesi, Bahçe Bitkileri Anabilim Dalı, Yüksek Lisans Tezi, Antalya, 58. (Investigations on Selection and Propagation Opportunities of Jojoba (Simmondsia chinensis L.) Plants Grown from Seeds in Antalya Ecology). M.Sc. Thesis, T.C. Akdeniz University Institute of Natural and Applied Sciences.

13. Ayanoğlu, F., 2001. Jojoba (Simmondsia chinensis Link. Schneider) ve Türkiye'de Yetiştirilebilme Olanakları III. Jojoba Yağı, Kullanım Alanları ve Ekonomik Önemi. [Jojoba (Simmondsia Chinensis Link. Schneider) and Its Culture in Turkey III. Jojoba Oil, Its Uses and Economical Importance], Anadolu Journal of the Aegean Agricultural Research Institute, 11(1), 103-112.

14. Öztürk, H.H., 2012. Enerji Bitkileri ve Biyoyakıt Üretimi, [Energy Crops and Biofuel Production]. Hasad Yayınevi, İstanbul, Turkey, 272.

15. Aftab, F., Akram, S., Iqbal, J., 2008. Estimation of Fixed Oils from Various Explants and In Vitro Callus Cultures of Jojoba (Simmondsia chinensis), Pakistan Journal of Botany, 40(4), 1467-1471.

16. Canoira, L., Alcántara, R., García-Martínez, J., Carrasco, J., 2006. Biodiesel From Jojoba Oilwax: Transesterification with Methanol and Properties as a Fuel, Biomass and Bioenergy 30, 76-81.

17. Marchetti, J.M., Miguel, V.U., Errazu, A.F., 2007. Possible Methods for Biodiesel Production, Renewable and Sustainable Energy Reviews 11, 1300-1311.

18. Shah, M., Tariq, M., Ali, S., Guo, Q., Fu, Y., 2014. Transesterification of Jojoba Oil, Sunflower Oil, Neem Oil, Rocket Seed Oil and 
Linseed Oil By Tin Catalysts, Biomass and Bioenergy, 70, 225-229.

19. Murashige, T., Skoog, F., 1962. A Revised Medium for Rapid Growth and Bioassays with Tobacco Tissue Cultures, Plant Physiology 15, 473-497.

20. Bouaid, A., Bajo, L., Martinez, M., Aracil, J., 2007. Optimization of Biodiesel Production from Jojoba Oil, Process Safety and Environmental Protection, 85(5), 378-382.

21. Aksoy, L., 2010. Alternatif Enerji Kaynağ Olarak Biyodizel ve Üretim Prosesleri [Biodiesel as an Alternative Energy Source and its Production Process], Electronic Journal of Vehicle Technologies, 2(3), 45-52.

22. Singh, S.P., Singh, D., 2010. Biodiesel Production Through the Use of Different Sources and Characterization of Oils and Their Esters as the Substitute of Diesel: A Review. Renewable and Sustainable Energy Reviews, 14, 200-216.

23. Yildizhan, Ş., Serin, H., 2015. Biodiesel Production from False Flax (Camelina Sativa) Oil and its Blends with Diesel Fuel, The Journal of MacroTrends in Energy and Sustainability, 3(1), 24-30.

24. Kaya, C., 2006. Bitkisel Yağlardan Biyodizel Üretimi [Biodiesel Production from Vegetable Oils]. M.Sc. Thesis, T.C. Dicle University Institute of Natural and Applied Sciences.

25. Selim, M.Y.E., Haik, Y., Al-Omari, S.A.B., Abdulrahman, H., 2011. Biodiesel Oil Derived from Biomass Solid Waste, Proceedings of the World Congress on Engineering, Vol III, London.

26. Selim, M.Y.E., 2009. Reducing the Viscosity of Jojoba Methyl Ester Diesel Fuel and Effects on Diesel Engine Performance and Roughness. Energy Conversion and Management, 50, 1781-1788.

27. Selim, M.Y.E., Radwan, M.S., Saleh, H.E., 2008. Improving the Performance of Dual Fuel Engines Running on Natural Gas/LPG by Using Pilot Fuel Derived from Jojoba Seeds, Renewable Energy, 33, 1173-1185.

28. Selim, M.Y.E., Radwan, M.S., Elfeky, S.M.S., 2003. Combustion of Jojoba Methyl Ester in an Indirect Injection Diesel Engine, Renewable Energy, 28, 1401-1420.
29. Radwan, M.S., Ismail, M.A., Elfeky, S.M.S., Abu-Elyazeed, O.S.M., 2007. Jojoba Methyl Ester as a Diesel Fuel Substitute: Preparation and Characterization, Applied Thermal Engineering, 27, 314-322.

30. Saribiyik, O.Y., Özcanli, M., Serin, H., Serin, S., Aydin, K., 2010. Biodiesel Production from Ricinus Communis Oil and its Blends with Soybean Biodiesel, Strojniski Vestnik-Journal of Mechanical Engineering, 56(12), 811-816.

31. Öğüt, H., Oğuz, H., 2006. Biyodizel: Üçüncü Milenyumun Yakıtı [Biodiesel: The Fuel of Third Millennium]. $2^{\text {nd }}$ ed. Ankara, Turkey: Nobel Yayınc1lı, ISBN: 975-591-730-6.

32. Abdel Fatah, M., Farag, H.A., Osman, M.E., 2012. Production of Biodiesel from Non-edible Oil and Effect of Blending with Diesel on Fuel Properties, Engineering Science and Technology: An International Journal, 2(4), 583-591. 
